\title{
Instruments for the protection of human rights violated during the study of human genome
}

\author{
Anna Dupan* and Juliana Bikbulatova \\ Higher School of Economics, Institute of Problems of Legal Regulation, 101000, Myasnitskaya St, 20, Russia
}

\begin{abstract}
The paper contains a comparative analysis of legal instruments used in the Russian legislation and in the legislation of other countries (Germany, Great Britain, USA, Japan) to protect (prevent violations, restore) human rights violated during the study of human genome. It was concluded that the existence of a comprehensive system of legal means for the protection and restoration of human rights violated during the study of human genome, is an incentive for the development of genomic research. In this regard, in Russia it is necessary to amend civil acts, Information, Criminal and Administrative Law in order to establish the peculiarities of the compensation for harm to human rights violations when studying human genome, special (different from the general) procedure for obtaining voluntary informed consent for genomic research, as well as special offences and administrative offenses committed during the study of the human genome.
\end{abstract}

\section{Introduction}

\subsection{Research carried out in the study of legal instruments for the protection of human rights in the study of genome}

The system of legal instruments used in Russian and foreign legislation (Europe, Japan, USA) to protect and restore human rights violated during the study of human genome was studied within the framework of the scientific project No. 18-29-14021 "Development of an integrated and socially effective system of legal means, ensuring the effective protection and restoration of the rights and interests of natural persons, disturbed in connection with the study of their genome, the genome of others, and as a result of unauthorized use of the results of these studies" funded by the Russian Foundation for Basic Research.

\subsection{Relevance and scientific novelty of the study of legal instruments for the protection of human rights in the study of human genome}

The relevance of this study is explained by the fact that as a debate arises on the complex aspects of human rights protection in genomic studies and the need to adopt specific legal norms it may be useful to study the practices of other countries that clarify possible options for the application of legal norms and identify international trends. Besides, genomic studies is becoming increasingly international with cross-border cooperation and data exchange [1].
The study of the human genome in Russia is one of the priorities of scientific and technological development, which suggests both positive effects, for example, an increase in funding for research projects of the human genome and an increase in the use of research results, as well as negative consequences, namely: an increase in the number of violations of human rights resulting from the study of human genome, the genome of others, unauthorized use of the results of such research.

Legal means for the protection of rights and restoration of violated rights (or remedy) are a set of measures (techniques) established by law, through which the stated purpose of protection is achieved: prevention of an offense, elimination of negative consequences of an offense, restoration of violated rights, compensation of losses suffered, etc. [2].

In genomic studies the potential subject to violations may be fundamental human rights enshrined in the Universal Declaration of Human Rights adopted on December 10, 1948, and detailed in the Universal Declaration on the Human Genome and Human Rights of 11.11 .1997 at the $29^{\text {th }}$ session of the UNESCO General Conference.

These rights include the following:

1) the right to liberty and physical integrity: no one can be subjected to medical, scientific or other experiments without voluntary consent;

2) the right to personal dignity: everyone has the right to respect for his dignity and his rights, regardless of his genetic characteristics;

3 ) the right to privacy, personal and family secrets, including the prohibition of collecting, storing, using and 
disseminating information about a person's private life without his or her consent;

4) the right to non-discrimination: the state guarantees the equality of human and civil rights and freedoms regardless of sex, race, nationality, language, origin, property and official status, place of residence, attitude to religion, beliefs, membership in public associations, as well as other circumstances.

It should be noted that these rights can be directly enshrined in the basic laws (constitutions) of all countries of Europe, the USA and Japan, and in the Constitution of the Russian Federation they are also directly enshrined (Articles 19, 21, 23, 24).

However, any right would remain a fiction unless it was effectively protected in the event of violations and restored after the violation. That is why it is essential to study the possible ways and mechanisms contained in the legislation of different countries through which human rights violated in the study of human genome are protected and restored. The results of comparative studies made it possible to conclude which set of tools is optimal (both for Russia and for other countries) in order to ensure a balance between stimulating human genome research and ensuring fundamental human and citizen rights.

\section{Results and Discussion}

\subsection{Classification of ways to protect rights violated in the study of human genome}

Despite the fact that in most foreign countries human genome research is regulated by law on the basis of the precautionary principle and maximum non-harm to humans [3], the main incentives for researchers to comply with all established requirements include a clear regulation of the grounds and limits of their responsibility for violation of certain human rights in the study of human genome.

There are different approaches to the classification of the branches of legislation in the legislation of different countries, but the fundamental division of instruments of law into private legal and public legal is present everywhere, and therefore the instruments of civil, information, criminal and administrative law used to protect and restore human rights in the study of humsn genome were found in the legislation of all studied countries.

Private legal methods are used to prevent the violation of human rights in genomic studies, and also allow effective restoration of rights in case of violations.

The instruments used to prevent the violation of human rights in genomic studies include the instruments of information law in the field of human genome research, which are used primarily to prevent the violation of human rights: informed voluntary consent to conduct research, establishing information with restricted access (secrecy) in relation to information obtained from human genome research.

The private legal ways to protect the violated rights in the field of human genome research, the most popular in the studied countries include the compensation for property and moral damage, the recovery of fines in favor of the victim, as well as the suppression of actions that violate the right or pose a threat to its violation. They also include disciplinary measures applied to employees who violated the rules of genomic research (reprimand, dismissal) during their work, and to employers for discrimination in connection with the results of human genome research. At the same time, researchers emphasize that the role of legal discourse, and in particular private law in terms of civil ways of protecting rights, should be focused on rethinking traditional institutions of compensation [4].

Public legal means of protecting rights include various measures of administrative and criminal responsibility for the violation of human rights in human genomic studies: fines, restriction or deprivation of liberty, deprivation of the right to engage in certain activities, deprivation and suspension of licenses.

\subsection{Private legal ways of protecting human rights in the study of human genome in various countries}

\subsubsection{Germany}

On August 27, 2008, Germany adopted the Law on Human Genetics Expertise (Ges etz über genetischeUntersuchungen bei Menschen), which focuses on the right to information and selfdetermination in order to protect people from abuse of their genetic information.

The legal field of Germany includes both the concept of the "right to knowledge" and the concept of the "right to ignorance". Both of these concepts are included in the concept of "informational self-determination" of a person [5] and are widely studied in the framework of scientific research (an example is a 2018 study on the prevalence of the decision on the "right to ignorance" among the German population [6]). The need for a "right to ignorance" may arise not only with respect to subjectconsistent genetic research, but also with respect to the emergence of the so-called "incidental complementary outcomes" beyond the original objectives of the study. Accordingly, civil remedies for the protection and restoration of rights also apply to the "right to ignorance".

Paragraph 4 of the German Law on the Human Genetics Expertise states that no one can be discriminated against or infringed on account of genetic characteristics. Insurers are allowed to request the results of analyses only if they purchase disability or pension insurance policies exceeding EUR 300,000 or which provide an annuity exceeding EUR 30,000 per year.

\subsubsection{USA}

In the United States, laws establishing the characteristics of human rights protection in genome research focus on the protection against discrimination, primarily in the field of labor and insurance legal relations, where civil 
law, labor and administrative legal means of protecting and restoring rights are also widely used.

In terms of civil remedies in the study of the human genome in the United States, civil fines are particularly interesting, i.e. a predetermined minimum amount of damages recovered in favor of the victim.

For example, Florida (USA) introduced the Bill HB 1189/SB 1564 [7], which allows individual plaintiffs recovering "all actual losses, including damage caused by economic, physical or emotional state that was caused as a result of unauthorized disclosure of genetic data", but at the same time establishes a minimum amount of compensable harm:

a) a fine of up to $\$ 1,000$ for negligent violations;

b) a fine of $\$ 1,000$ to $\$ 5,000$ for intentional violations.

The greatest development in the field of protection and restoration of employee rights during genomic research was received in the USA in accordance with the Genetic Information Nondiscrimination Act (GINA) [8], which entered into force in 2009.

In the United States, an employee who believes that he was subject to workplace discrimination in connection with his genome research must file an application - a claim of discrimination to the U.S. Equal Employment Opportunity Commission (EEOC) before he can sue in federal court for employment discrimination in compliance with Section VII of the Civil Rights Act of 1964. EEOC investigates complaints under Section II of the GINA. An employee has the right to refuse to work if it is impossible to work in discriminatory conditions. In the case of a claim for monetary compensation, its amount will be limited if the applicant is unemployed by the amount of three months' salary.

\subsubsection{Great Britain}

In the UK, the judiciary develops precedents describing the conditions for disclosing genetic information to relatives: how to answer questions of genetic relatives of a study participant about their own risk or whether researchers should warn relatives about the potential genetic risk.

For example, in the case of ABC v St. George's Healthcare NHS Trust et al. 2015 EWHC 139 [9], a pregnant daughter who accidentally learned about her father's genetic disease and was not a patient of the doctor treating her father, sued the treating doctor for violation of the duty of information "care" in connection with the following circumstances.

In 2009, the complainant's father was diagnosed with the Huntington's disease, which is an extremely serious disease of genetic origin, which leads to inexorable mental and physical disorders during the patient's lifetime. So far, there is no treatment for this disease. If a parent has a disease, there is a $50 \%$ chance that his or her child will inherit it.

In connection with this, various health professionals demanded the consent of the accused to reveal his diagnosis to his daughter, who was at an early stage of pregnancy and examined in the same clinic, with the same doctors. But the father refused to let medical staff tell his daughter about this diagnosis. They did not, and the complainant's daughter was born in April 2010. Subsequently, it turned out that the deponent also has the Huntington's disease.

The complainant claimed that the concealment of information about her father's condition was a real negligence on the part of the accused and a violation of her rights related to "information care". She claimed that if she had been informed of her father's condition, she would have passed a test to check if she had the disease and immediately ended her pregnancy upon learning of the disease. She argued that if her daughter was diagnosed with the disease, the deponent would also incur additional costs that could otherwise have been avoided.

The court studied all the above arguments and refused to satisfy the claim, since the duty of care that the plaintiff tried to establish was "completely new" within the framework of existing legal relations. In any event, there is an obvious balance between the value for the plaintiff to know that her father had this genetic disease on the one hand and her father's right to keep his medical information confidential, which is the fundamental right of the patient [10].

Such judicial practice obviously does not meet social expectations: society believes that the doctor must (even against the patient's wishes) warn his relatives whose health is at high risk (including future children), provided that all attempts to convince the patient to disclose information voluntarily failed and only genetic information directly related to the medical condition of relatives is disclosed.

To resolve the conflict between legal and social norms, WHO experts are trying to develop effective legal instruments to regulate situations of forced violation of patients' personal data: in particular, the idea is being discussed that the decision to violate confidentiality and disclose information to relatives should be made not by one specialist, but by ethics committees, which can be an effective solution.

Also in the UK, labor law instruments are actively used in the protection of human rights violated in connection with the study of human genome. In particular, employees may file discrimination claims with the Employment Tribunal. Besides, claims can be settled by the Advisory, Conciliation and Arbitration Service (ACAS), any decision is binding. Compensation is the main remedy in the UK - compensation for damage and loss of income. The amount of compensation varies from GBP 900 to GBP 44,000 depending on the form of discrimination and its duration.

\subsubsection{Japan}

In Japan, most cases of restoration and protection of rights violated in labor relations in connection with genome research take the civil legal form. There are no restrictions on the period during which the employee can declare his demand to cancel the dismissal. However, the 
court may not accept an employee's claim based on the principles of loss of right in accordance with the principle of good faith (Civil Code, Article 1 (ii)) if the claim is filed many years after dismissal. In Japan, there is no "group action" system that allows an employee representing the interests of the group in a lawsuit, but employees can file a lawsuit collectively. Even if more than one claim is filed separately, such claims may be combined if the rights or obligations that are the subject of the claims are common or based on the same factual or statutory cause.

An employee may require the recognition of discriminatory acts (dismissal, for example) as invalid; restoration of previous conditions, opportunities, rights; compensation for discrimination, including nonpecuniary damage. In Japan, an employee cannot claim punitive damages [11].

\subsubsection{Russian Federation}

In Russian legislation, on the one hand, there are no special rules establishing the procedure for applying private legal methods to protect rights violated during the study of the human genome, and on the other hand, the application of general rules on the protection of personal data, on the protection of patient rights to violations in the field of genomic studies causes difficulties due to the blurring of existing definitions.

Thus, in Russian legislation, when conducting gene therapy [12] and medical and genetic examination [13, 14], all methods of protecting the rights of a patient provided for by the Federal Law No. 323-FZ "On the basics of protecting the health of citizens in the Russian Federation" of 21.11.2011 can be applied, however, with genodiagnostics [12] and human cloning [15], the question of direct application of this law remains open, since it is impossible to draw a direct conclusion from the normative definitions of genodiagnostics and cloning about the presence or absence of medical interventions during their implementation and, therefore, apply the Federal Law "On the basics of protecting the health of citizens in the Russian Federation".

Besides, the legal definition of gene therapy states that exclusively non-inherited modifications of the genome are regulated in Russia [16], which is a gap in the conditions for the application of modern achievements in the field of genomic studies (first of all, we are talking about the CRISPR-Cas9 method, which provides the possibility of editing the genes of human embryos and reproductive cells).

Researchers note that activities related to genetic modifications and gene therapy have been the subject of debate and controversy for more than one year, but the discovery of the CRIPSP-Cas9 method has led to the greatest contradictions [17]. Undoubtedly, this is caused by the fact that the method allows accurately removing the damaged gene and replacing it with the correct one. This method is much cheaper, simpler, safer and faster than those previously used. This method can be used for genetic modification of plants, animals and humans. Therefore, this is the first method that makes it possible to control the randomness of evolutionary processes in all nature [18].

Under these conditions, Russian legislation should define the procedure for the protection of human rights when carrying out inherited modifications of the genome (embryo gene editing), and solve complex issues on the time frame for the protection of these rights, taking into account the fact that harm can be caused to the children and grandchildren of the person whose genes were edited $[19,20]$.

Moreover, modern technologies require solving the issue of the conditions under which such editing is permissible, taking into account the unpredictability of side mutations and the complexity of providing all objective information to the patient to obtain consent (due to the lack of clarity of the researchers themselves on many issues) that was confirmed by the discussion around Denis Rebrikov's intention to deactivate a gene encoding a protein that allows HIV to enter embryo cells [21].

With regard to civil and labour means of protecting human rights when conducting research on human genome, there are only two references in legislation: in part 3 of Article 10 of the Federal Law No. 242-FZ "On state genomic registration in the Russian Federation" of 03.12.2008, which gives a general reference to the legislation of the Russian Federation in violation of the rules for processing genomic information by officials of state bodies and institutions conducting state genomic registration, and persons who have gained access to genomic information, as well as in Article 12 of the Federal Law No. 86-FZ "On state regulation in the field of genetic engineering activities" of 05.07.1996, which also gives a general reference to the legislation of the Russian Federation when causing damage to employees of an organization engaged in genetic engineering activities, the population, and the environment.

It is obvious that citizens of the Russian Federation can apply general civil law norms on liability for harm caused when their rights are violated during genomic studies (property and moral), including through medical intervention, general rules of information law for violations in the field of personal data processing, as well as general rules of labor law prohibiting discrimination if a person was harmed as a result of studies of his genome or the genome of others.

However, given the difficulties in proving the fact of harm and the amount of damage in civil proceedings in Russian courts, difficulties in proving discrimination in employment or in establishing working conditions on the basis of genetic data in a labor dispute, it becomes apparent that the application of the existing rules on civil, disciplinary, criminal, administrative responsibility for specific human rights relationships is ineffective in conducting research on human genome.

With regard to information legislation, Article 11 of the Federal Law No. 152-FZ "On personal data" of 27.07.2006 does not explicitly include genetic data in biometric personal data, and before the adoption of the Draft Law No. 744029-7 on amending Article 11 of the said law, it is impossible to say with complete certainty that at present, the entire arsenal of information 
legislation used to protect biometric data can be applied to cases of violations in human genomic studies.

\subsection{Public legal ways to protect violated rights in the study of human genome in different countries}

Germany has a developed system for administrative and legal protection of the rights of persons whose genomic information is processed. For example, an administrative fine of up to EUR 300,000 is imposed for violations including misuse of a genetic sample and failure to destroy it after the study, failure to obtain the consent of the subject before the genetic study, providing the results of the study to a representative of the insurance company or employer, as well as when hiring.

A fine of up to EUR 5,000 in Germany is imposed for violations including violations in the genetic examination of a child, as well as of his father or mother in order to determine kinship. At the same time, the administrative authority should not initiate prosecution in the case where a person whose genetic samples were used to determine kinship gave his consent after conducting research and taking samples.

Violations of all other legal provisions in the field of human genome research entail a fine of up to 50,000 euros.

Japan puts great emphasis on the system for assessing the need and implementation of genetic research itself, which includes, in addition to a research institution, medical communities and federal legislatures. In this regard, many institutions require that clients necessarily visit a therapist before concluding a genetic research contract with a research institution [22].

Criminal law instruments can be applied to legal relations governing the study of human genome thus incriminating acts and referring them to various types of crimes:

1) special elements of crimes established for the field of work with the human genome, for example: deliberate change of the genome of embryo cells and embryos; non-compliance with the terms of the genetic study; unauthorized use of a genetic sample and its nondestruction after the study; failure to obtain the consent of the subject prior to the genetic examination; providing the results of the study to the representative of the insurance company or the employer; irregularities in the genetic examination of a child, as well as of a father or mother to determine the kinship; intentional or negligent violation resulting in economic, bodily or emotional harm; purchase, storage or use of gametes or other genetic information without the written and informative consent of the gamete supplier;

2) general elements of crimes that may be applied to legal relations in the field of genetics taking into account the nature of the act committed.

For example, in the UK, several types of acts related to the study of the human genome were criminalized, for example, anyone who purchases, stores or uses gametes or other genetic information without the written and informative consent of a gamete supplier commits a criminal offense, which entails imprisonment for a maximum of 12 months or a fine not exceeding the maximum prescribed by law; or imprisonment for a term not exceeding 3 years or a fine [23].

In Japan, South Korea, the USA and the EU there are also criminal prohibitions on clinical studies involving modifications of the germ line of the human genome [24].

The situation with the protection of human rights in the study of human genome in Russia is complicated by the fact that both the Criminal Code of the Russian Federation and the Code of Administrative Offenses do not contain any corpus delicti/offense directly related to human genome research, and even the violation of the ban on human cloning will not entail any criminal proceedings or administrative offense.

\section{Conclusions}

The study of legislation and law enforcement practices of the countries of the European Union, USA, and Japan proves that there is a clear system of legal means to protect and restore human rights violated in the course of studies of human genome, the genome of other persons. Besides, it is an incentive for the development of such research since bothe the researcher and the citizen and other concerned persons clearly understand what the state permits, prescribes or prohibits when conducting research on the human genome, and the responsibility it might entail.

For these reasons, the legislation of the Russian Federation should be amended to increase the effectiveness of various methods of protecting the violated rights in the study of human genome.

\subsection{Civil law}

Within the framework of the civil legislation of the Russian Federation it is necessary to establish the features of compensation for damage when conducting research on the human genome, namely, to provide for the possibility for a victim to recover compensation instead of compensation for damage, the minimum amount of which is established in the legislation (by analogy with the compensation for violation of exclusive rights stipulated in the Civil Code of the Russian Federation).

In fact, compensation is a civil fine, which, unlike an administrative fine, is collected in favor of the victim himself, and not into the state budget. This will make a complainant sure that in any case he will receive the minimum compensation established by law for the violation of his rights when conducting genomic research.

Violations for which the civil law may establish a compensation may include violations in the field of obtaining informed consent, disclosure of information obtained during human genome research. 


\subsection{Information and health legislation}

Legislation on the protection of the health of citizens should define the procedure for the protection of human rights when carrying out inherited modifications of the genome (embryo gene editing), and solve complex issues concerning the period of protection of these rights taking into account the fact that harm may be caused to children and grandchildren of a person whose genes were edited.

It is advisable that the information legislation of the Russian Federation includes special requirements for the provision of voluntary informed consent for genomic research, which differ from the general ones established by the legislation on the protection of citizens' health.

It is also necessary to establish cases in which the results of research may be disclosed without the consent of a person in respect of whom the genomic studies were conducted, the circle of persons to whom such results may be disclosed, as well as a special procedure for deciding on the disclosure or non-disclosure of such results, for example, the creation of a special commission with the participation of doctors and lawyers.

\subsection{Administrative and criminal legislation}

The administrative and criminal legislation of the Russian Federation suggests introducing special administrative offenses or criminal offenses that target human rights violated as a result of the study of human genome, the genome of other persons, the unauthorized use of the results of such a study, for example:

- human cloning;

- deliberate genome change of germ cells and embryos;

- non-compliance with the conditions of genetic research;

- unauthorized use of the genetic sample and its nondestruction after the study;

- failure to get the informed consent of the subject prior to the genetic examination;

- irregularities in the genetic examination of a child, as well as of a father or mother to determine the kindship;

- purchase, storage or use of gametes or other genetic information without the written and informed consent of the gamete supplier.

\section{References}

1. R. Branum, S.M. Wolf, International Policies on Sharing Genomic Research Results with Relatives: Approaches to Balancing Privacy with Access, Journal of Law, Medicine \& Ethics, 43(3) (2015)

2. A.P. Vershinin, Choice of a method for protecting civil rights (St. Petersburg, 2000) p. 35

3. K.P. Rippe, A. Willemsen, The idea of precaution: Ethical requirements for the regulation of new biotechnologies in the environmental field, Frontiers in Plant Science, 871, 1868 (2018)

4. D. Krekora-Zając, Civil liability for damages related to germline and embryo editing against the legal admissibility of gene editing, Palgrave Commun., 6, 30 (2020). DOI: https://doi.org/10.1057/s41599020-0399-2

5. R. Wagner, Ethical Aspects of the German Genetic Diagnostics Act, Deutsches Referenzzentrum fur Ethik in den Biowissenschaften (2016). Retrieved from: http://www.drze.de/in-focus/predictivegenetic-testing/ethical-aspects

6. L. Flatau et al., Genomic information and a person's right not to know: A closer look at variations in hypothetical informational preferences in a German sample, PLoS ONE, 13(6), e0198249 (2018).

7. HB 1189: Genetic Information for Insurance Purposes. Retrieved from: https://www.flsenate. gov/Session/Bill/2020/1189

8. H.R.493 - Genetic Information Nondiscrimination Act of 2008. 05/21/2008 Became Public Law No: 110-233. Retrieved from: https://www.congress. gov/bill/110th-congress/house-bill/493/text.

9. ABC v St. George's Healthcare NHS Trust [2015] EWHC 139. England and Wales High Court (Queen's Bench Division) Decisions. Retrieved from: http://www.bailii.org/ew/cases/EWHC/QB/ 2015/1394.html.

10. T.W. Baker, The Legal Aspects of Health Care Business Transactions: A Complete Guide to the Law Governing Health Industry Business Organization, Transactions, and Governance (Coronat Services, LLC, 2018)

11. O. Shiho, Y. Kanamaru, Japanese Employment Law (2020). Retrieved from: https://iclg.com/practiceareas/employment-and-labour-laws-andregulations/japan.

12. Federal Law of 05.07.1996 No. 86-FZ "On State Regulation in the Field of Genetic Engineering". Collection of Legislation of the Russian Federation, No. 28, Art. 3348 (1996)

13. Family Code of the Russian Federation. Collection of Legislation of the Russian Federation, No. 1, Art. 16 (1 January 1996)

14. Federal Law of 21.11.2011 No. 323-FZ "On the Basics of Protecting the Health of Citizens in the Russian Federation". Collection of Legislation of the Russian Federation, No. 48, Art. 6724 (28 November 2011)

15. Federal Law of May 20, 2002 No. 54-FZ “On a temporary ban on human cloning". Collection of Legislation of the Russian Federation, No. 21, Art. 1917 (27 May 2002)

16. N.V. Bogatyreva, V.E. Rossik, V.A. Bogatyrev, N.V. Shishkinskaya, Commentary on the Federal Law of July 5, 1996 N 86-FZ "On State Regulation in the Field of Genetic Engineering" (itemized). 
Retrieved from: "Consultant" Reference Legal System

17. I. De Miguel Beriain, A.M. Marcos del Cano, Gene editing in human embryos. A comment on the Ethical Issues Involved. In: Soniewicka (2018)

18. T. Ishii, Germ line genome editing in clinics: the approaches, objective and global society, Brief Funct. Genomics, 16(1), 46-56 (2017). Retrieved from: https://www.ncbi.nlm.nih.gov/pmc/articles/ PMC5291189/.

19. J.A. Doudna, S.H. Sternberg, A crack in creation: gene editing and the unthinkable power to control evolution (Houghton Mifflin Harcourt, Houghton, 2017)

20. J. Savulescu, J. Pungh, T. Doiglas, Ch. Gyngell, The moral imperative to continue gene editing research on human embryos, Protein Cell, 6(7), 476-479 (2015). Retrieved from: https://www.ncbi.nlm.nih.gov/pmc/articles/PMC449 1050
21. Russian biologist plans more CRISPR-edited babies (10.06.2019) Retrieved from: https://www.nature.com/articles/d41586-019-01770$\mathrm{x}$

22. Ethical Guidelines for Human Genome, Gene Analysis Research March 29, 2001 with the amendments as of 2013. Retrieved from: https://www.mhlw.go.jp/file/06-Seisakujouhou10600000-

Daijinkanboukouseikagakuka/0000153405.pdf

23. Human Tissue Act (2004). Retrieved from: http://www.legislation.gov.uk/ukpga/2004/30/sectio $\mathrm{n} / 32 /$ enacted

24. A. Boggio, C. Romano, J. Almqvist (Eds.), Human Germline Genome Modification and the Right to Science: A Comparative Study of National Laws and Policies (Cambridge University Press, 2019) pp. 241-265 